Sri Lankan Journal of Librarianship and Information Management

Vol.4, Nos. 3\&4 (July - Dec.2011) pp. 59 -75.

\title{
The Historical Development of Sri Lankan Scholarly Journal Publishing (1845 - 2010)
}

\author{
Geetha Yapa \\ Science Reference Librarian University of California Riverside \\ P.O. Box 5900 Riverside, CA 92517-5900, \\ USA \\ Tel. 951-827-6442 \\ Fax 951-827-2820 \\ geethay@ucr.edu
}

\begin{abstract}
Sri Lanka has a long history of writing and literary activities with historical records and archival evidence dating back to the 3rd century BC. Introduction of Buddhism marked the beginning of a new culture, and an era of academic and literary activities commenced during the 1st century BC when Buddhist scriptures were first committed to writing. However, scholarly journals or periodicals based on systematic organized research came into existence during the early 19th century when the country was under British colonial rule. While few important journals from the colonial era still continue, an increasing number have emerged over the years reflecting the country's expanding academic and research environment. This paper recounts the last 165 years of evolution and progress in Sri Lankan scholarly journal publications from 1845 to 2010.
\end{abstract}

Keywords: Academic journals, Scholarly publishing, Periodicals, Sri Lanka

\section{Introduction}

Scholarly publications play an important role in facilitating communication and exchange of ideas between scholarly writers and scholarly readers. Earliest communications between scholars were based on personal contact and meetings organized by learned societies provided scholars with the opportunity to share information. Over time proceedings of learned societies became a vehicle through which scholars were able to reach a wider community. One of the first scholarly journals to be published was the journal Le journal des sgavans (Journal of Learned Men), in 1665, followed by Philosophical Transactions of the Royal Society (Porter, 1964). These publications served as models to subsequent academic journals. Scholarly publishing gradually increased with the founding of educational institutions and learned societies.

The general layout of articles and the format of journals have evolved over the years with increased specialization, appearance of abstracting journals and transition from print to electronic versions. The scholarly publishing transformation in Sri Lanka over the years reflects not only technological changes, but also the political, social, cultural 
and economic history of the country.

\section{Colonial history}

The beginnings of scholarly publications based on scientific investigations in Sri Lanka could be traced back to the time when the country was under European colonial administration. The first to arrive were the Portuguese in 1505 . There were hardly any scientific studies during the time the Portuguese were in Sri Lanka (Ceylon at the time), since they were mainly interested in trade and commerce. The Portuguese were later succeeded by the Dutch in the late 1600 s. The Dutch were the first to begin scientific investigation of natural history in the country. Although the first printing press in Sri Lanka was introduced in 1734 by the Dutch, publications based on the study of local flora and fauna conducted by Dutch scholars were published elsewhere.

Scholarly periodical publishing in Sri Lanka began in the early 19th century by British scholars, when the country was under British colonial administration. The British took over the country from the Dutch in 1796; in 1815 Sri Lanka became a crown colony. Establishment of a British community led to the formation of learned societies in the country, followed by the appearance of periodicals. The Ceylon Government Gazette, which commenced publication in 1802, was the first periodical to be published in Sri Lanka. Scientific papers presented at the Ceylon Literary Society were selectively published in the Gazette. Colombo Journal, the first newspaper published in Sri Lanka in 1832 also contained articles on literary and scientific topics (Senadhira, 1975). The founding of the first periodical was followed by a gradual increase in periodical publications. However, most of the early periodicals such as the Friend, Colombo Magazine, Ceylon Miscellany were short-lived. According to the Calcutta Review, periodicals founded during early 19th century "lived the average life of Ceylon periodicals -2 years" (The Periodic Literature of Ceylon, 1849). The Journal of the Ceylon Branch of the Royal Asiatic Society is the first scholarly journal published during the 19 th century to continue through to the 21 st century.

Progress in scholarly publishing during the 19th century was closely related to the historical development of learned societies in the country. The Journal of the Ceylon Branch of the Royal Asiatic Society was first published by the Asiatic Society of Ceylon, founded in 1845 to "institute and promote inquiries into the history, religion, literature, arts, and natural philosophy of Ceylon, together with the social conditions of its present and former Inhabitants" (Journal of the Ceylon Branch of the Royal Asiatic Society,1845). The Society "afforded Ceylonese an opportunity to pursue knowledge at closer quarters, and later even participate in historical and literary research on equal terms with educated Englishmen" (Gooneratne, 1966). Journal of the Ceylon Branch of the Royal Asiatic Society remained the main publication carrying articles of scholarly nature from a multitude of subject areas for nearly half a century. The journal which started as a medium for communicating information on oriental and antiquarian topics also served the areas of natural history, fisheries, geography, and geology until the emergence of specialist journals during the early half of the 20 th century. Over the years, the subject coverage of the journal has reverted back to the original mission of 
covering areas related to the history of the country.

Late 19 th century and early 20 th century saw the emergence of several periodicals that catered to the interests of the orientalists and antiquarians. These included Ceylon Literary Register (1886), the Ceylon National Review (1906), and the Ceylon Antiquary and Literary Register (1915). However these periodicals had ceased publication by mid 19 th century, leaving Journal of the Ceylon Branch of the Royal Asiatic Society with the responsibility of covering the subject areas of History, Religion, Literature, Arts, and oriental studies.

The first scientific journal to be published in Sri Lanka was the Medical Miscellany, which formed part of a periodical named Ceylon Miscellany, founded in 1853 (Senadhira, 1975). This publication provided an avenue for communicating medical information. The development of health services to serve the government and the plantation industry led to the establishment of the Ceylon Medical School in 1870, followed by the founding of the Ceylon Branch of the British Medical Association in 1887. The Ceylon Medical Journal (the second longest running periodical in Sri Lanka) was first published in August 1887. The name changed to Journal of the Ceylon Branch of the British Medical Association in 1904, but changed to its "pristine appellation in 1952, and continues to be published as the Ceylon Medical Journal (CMJ). It is the oldest surviving English language medical journal in Asia and Australasia, and is the leading scientific journal in Sri Lanka" (http://cmj.slma.Ik/cmj53s1/cmj53s1.pdf). It is the only periodical in Sri Lanka to be indexed continuously by an international indexing and abstracting service (at first in Index Medicus, now PubMed, since 1952).

The influx of Europeans for Civil service and the establishment of the plantation system during the 19th century gave rise to the need for scientific journalism. Although there was a gradual increase in periodical publications, "almost the only works that were extensively read were subjects alluding to coffee planting" (The Periodic Literature of Ceylon,1849). The Tropical Agriculturist was founded in 1881 by A.M. \& J Ferguson, publisher of the newspaper Ceylon Observer, in response to the need for a venue for exchange of information on tropical agriculture and colonial industries. The Ceylon Agricultural Society, founded in 1904 by the colonial government with the view of developing the agricultural industries, took over the publication of Tropical Agriculturist and it continues to be published by the Department of Agriculture. The journal, which began as a monthly record of information for planters gradually transformed into a truly scientific journal becoming "the oldest journal in the world devoted to tropical agriculture" (Schokman, 1981).

It "helped to establish Ceylon's reputation as one of the most important centres of 'scientific agriculture' in the empire" (Hodge, 2002). Limited availability of publications at the time led to broader subject coverage that included veterinary science, forestry, geography and meteorology. However, the focus of the journal narrowed to food crops with the emergence of specialized journals for plantation crops and other subject areas. 
The arrival of British administrators from the East India Company catalyzed the establishment of scientific institutions and expert appointments to study the natural history of the country. One of the first steps taken by the new colonial rulers was to establish botanical gardens (Archer, 1959). The establishment of the first English Botanic Garden in Sri Lanka in 1810 sparked increased scientific activity involving the collection, classification and description of wild plants and the emergence of Annals of the Royal Botanic Gardens Peradeniya in 1901, the first official journal published by the government. Topics covered in the journal indicate the scientific trends in the island during the middle of the century where activities of the Botanic gardens moved towards the "introduction and acclimatization of numerous useful valuable plants from other parts of the world" and study of insects and fungi causing harm to plants (possibly due to the destruction of coffee plantations) as the government moved towards economic botany (Willis, 1901).

With the opening of the National Museum in 1887, a journal that dealt primarily with fauna came into existence with the founding of Spolia Zeylanica in 1904. The journal was "designed to promote a knowledge of the natural history of Ceylon (exclusive of botany) for the information of residents and also for the advancement of science" and included economic and systematic knowledge of natural resources (zoology, anthropology and geology) (Spolia Zeylanica, 1904). This journal became the major zoological journal published in Sri Lanka attracting publications based on zoological investigations which previously were published in the Journal of the Ceylon Branch of the Royal Asiatic Society.

The growth of the plantation industry led to the establishment of research institutes to cover main plantation crops - tea and rubber - during the early part of the 20 th century. The emergence of research institutes and the corresponding rise of local scientific communities led to the publication of their own scientific and technical journals, beginning with the Bulletin of the Rubber Research Scheme (Ceylon) in 1913, followed by Tea Quarterly in 1928. Quarterly Circular of the Rubber Research Scheme published during the early 20 th century later transformed into a scientific journal Quarterly Journal of the Rubber research Institute and continues to be published as the Journal of the Rubber Research Institute.

The foundations of systematic archaeology in Ceylon were laid by the British government in the second half of the 19 th century with the establishment of the Archaeology Commission in 1869 which later became the Department of Archaeology in 1890. Reports on the Archeological Survey of Ceylon appeared as part of the Ceylon Administration Reports. However, there was an expressed need for the separation of epigraphy from archaeology (Geiger, 1898). This resulted in the publication of Epigraphia Zeylanica in 1904, the first journal on the subject of ancient writings in Sri Lanka.

Although the British were at first interested in the exploitation of natural resources, they gradually began to take an interest in conserving the environment. First steps towards nature conservation began in 1885 with the enactment of the Forest ordinance. The 
Wildlife Protection Society which started as the Game Protection Society in 1894 for the purpose of conservation for hunting gradually changed its purpose towards education and scientific investigations (Crusz, 1973). The journal Loris launched in 1936, by the Wildlife Protection Society provided a venue for publishing articles on Sri Lankan wildlife and continues to provide a great service promoting wildlife and nature conservation.

The educational system in Ceylon expanded under British colonial times to create an educated class to support administrative and professional services in the country. The expansion of formal education and the establishment of University College in 1921 stimulated research investigations and extension of research into many subject areas. This resulted in increased publications dealing with a wide range of subjects from natural sciences, physical sciences and archaeology etc. In 1924, Ceylon Journal of Science was created to accommodate the increased output from different branches of science by bringing together the existing journals published by government institutions and separating them into sections. Additional sections were created to accommodate the expansion of subject areas. Thus Annals of the Royal Botanic Gardens, Peradeniya (first published in 1901), the Spolia Zeylanica (first published in 1903) and the Bulletin of the Ceylon Fisheries (first published in 1923) were issued under the common title, Ceylon Journal of Science and published separately under sections A, B, and C, along with additional sections $D, E, F$ and $G$ covering the following subject areas; Medical Science (D), Mathematics, Physics and Meteorology incorporating the Bulletin of the Colombo Observatory ( E), Chemistry (F) and Archaeology and Ethnology (G).

With the elevation of the status of University College to University of Ceylon in 1942, the administration of the Ceylon Journal of Science was transferred to the University. Spolia Zeylanica reverted to its original status of a separate publication managed by the Colombo National Museum. Section D became Ceylon Journal of Medical Sciences and continues to be published by the University of Colombo. Publications by the University were further expanded by the inauguration of the University of Ceylon Review in 1943. This journal filled a critical void in University publications by providing a forum for the output of articles on a wide variety of topics ranging from philosophy to literature, humanities and social sciences.

Although the Tropical Agriculturist contained materials of geographical interest there was no periodical devoted to the geography of the island until the appearance of the Ceylon Geographer (Bulletin of the Ceylon Geographical Society) in 1945. It is one of the last scholarly periodicals launched during the British period.

\section{Scholarly publishing since independence}

\section{The 1950s}

Sri Lanka regained independence from British colonial rule in 1948, and the decade that followed showed a marked increase in the number and diversity of journal published in the country. One of the first scholarly periodicals to emerge after independence was the Ceylon Coconut Quarterly in 1950, which published popular articles on topics of interest 
to coconut growers and others engaged in the coconut industry, including the results of research pursued under the Coconut Research Scheme.

The Coconut Research Institute of Sri Lanka (CRISL) was initially established as the Coconut Research Scheme in 1928, and most of the articles relating to coconut were published in Tropical Agriculturist until the appearance of Ceylon Coconut Quarterly. This journal is continued as Cocos from 1983.

Publications by other government institutes during this period include the Bulletin of the Fisheries Research Station founded in 1952 and the Ceylon Forester in 1953. The Bulletin of the Fisheries Research Station provided a place for scientific communication of research reports by the Ceylon Fisheries Research station while the Ceylon Forester published by the Ceylon Forest Department covered reports of scientific investigations that highlight the move towards forest conservation.

There were no periodical publications devoted solely to matters related to the history of Ceylon until the founding of Ceylon Historical Journal in 1951, by a commercial publisher. This journal began as a series of monographs but it also included scholarly articles. Although publication of this journal ceased after some years, the trend towards publishing articles related to historical and social aspects continued with the publication of Ceylon Journal of Historical and Social Studies by the Ceylon Historical and Social Studies Publications Board in 1958. The Journal of the National Education Society, one of the first journals to cover the subject of local education appeared some time during the 1950 s and ceased publication during the 1970s.

Ceylon Journal of Science continued to evolve and change over the years. In 1957 sections $A, B$, and C comprising Botany, Zoology, and Fisheries were united to form the Ceylon Journal of Science (Biological Sciences) new series. This continues to be published by the University of Peradeniya. The former Sections E and F (Mathematics, Physics, Meteorology and Chemistry) are published by the University of Peradeniya as the Ceylon Journal of Science (Physical Sciences - founded in 1958) which now includes Computer Science, Geology, Mineralogy, Science Education and Statistics. Section G (Anthropology, Archaeology and Ethnology) has not been published since Vol. 5 (1957).

Although the Ceylon Veterinary Association was established in 1940, their first publication - the Ceylon Veterinary Journal - appeared in 1953, following the increase in veterinarians and research personnel in the field of veterinary science with the establishment of the Department of Veterinary Science at the University of Ceylon in 1947. Articles relating to veterinary science were previously published in Tropical Agriculturist.

\section{The 1960s}

Compared to the 1950s, fewer new scholarly periodicals and journals were introduced during the 1960s. The Coconut Research Institute began publishing the Coconut 
Planters' Review in 1960 to provide coconut planters with information on all aspects of the coconut plantation industry in non-technical language. Another agricultural periodical, the Journal of the National Agricultural Society, was founded in 1963 adding to the growing number of agricultural publications. In the medical field, the Ceylon Journal of Child Health was founded in 1963 by the Ceylon Paediatric Association (established in 1952, with the aim of promoting child health care in Ceylon).

Vidyodaya Pirivena, a premier Buddhist institute of higher education, was accorded university status in 1958. The establishment of the Vidyodaya Campus of the University of Ceylon resulted in an increase in research activities in the fields of humanities and social sciences leading to the 1968 publication of the University's first periodical, Vidyodaya Journal of Arts, Science and Letters. This publication was later continued by Vidyodaya Journal of Social Science and now continues as the Vidyodaya Journal of Humanities and Social Science. Another University publication, the Colombo Law Review was founded in 1969 after the establishment of the Faculty of Law at the Colombo Campus in 1968.

\section{The 1970s}

From 1970 onwards there is a significant increase in the publication of scholarly journals in Sri Lanka. A number of learned societies and banks started journal publication during the 1970s expanding the subject areas covered by Sri Lankan periodicals. New areas of research publications included soil science, dentistry, engineering and economics. The Soil Science Society of Sri Lanka established in 1969 with professional members from universities, government and research institutions, published the Journal of the Soil Science Society of Sri Lanka in 1970. Scientific investigations on soils had been included in Tropical Agriculturist up to this time. The formation of the Ceylon Dental Association 1933 and the establishment of the Department of Dental Surgery in the faculty of Medicine University of Colombo in 1943 led to research on oral health resulting in the publication of the Ceylon Dental Journal by the Sri Lanka Dental Association in 1970. The Sri Lanka Journal of Surgery was first published in 1974 by the College of Surgeons of Sri Lanka and the Sri Lanka Journal of Obstetrics and Gynecology published by the Sri Lanka College of Obstetricians and Gynecologists first appeared in 1979.

The Social Scientists Association formed in 1977 founded the journal Social Science Review in 1979 which published original research on society, history, politics and political economy. Periodicals devoted to engineering did not appear until 1974 when the Engineer was launched by the Institution of Engineers (established in 1956, the successor to the Engineering Association of Ceylon which was founded in 1906).

Banks emerged as academic publishers when the Central Bank of Ceylon founded the journal Staff Studies during the early 1970s and the Peoples Bank started publishing Economic Review in 1975. Both journals include literature on economic aspects of the country, including topics on economic development, inflation and financial management. 
Two more publications in the area of humanities and social sciences were founded by universities during the 1970s. The first to arrive was the Ceylon Journal of the Humanities, published by the Peradeniya Campus in 1970. The Jaffna Campus of the University of Sri Lanka was established in 1974 and the first periodical publication by the University, Sri Lanka Journal of South Asian Studies, emerged in 1976.

Publications issued by research institutions during 1970s include Marga (Marga Institute, 1971), covering research on issues and problems of development including economics, sociology and political science, Journal of the National Science Council of Sri Lanka (covering scientific research) and the Sri Lanka Journal of Social Science were published by the National Science Council established in 1968.

Ancient Ceylon: Journal of the Archaeological Survey of Ceylon (a government publication) was launched in 1971, encouraging discussion of archaeological topics and taking a modern approach to antiquarian research (Bronson, 1975).

\section{The 1980s}

The 1980s were associated with the launching of the highest number of periodicals by Sri Lankan universities. The expansion of the university system with the addition of new universities in different parts of the country, the establishment of postgraduate institutes and research institutes all played a major role in increasing the research output of the country. The first to appear was the University of Colombo Review in 1981. This multidisciplinary publication includes a wide range of subjects ranging from climate, history, philosophy, education and law. The University of Moratuwa, established in 1978, came up with the publication of Development Planning Review in 1982 which provided an academic outlet for publications in a new field of study related to urban development. Vidyalankara Campus of the University of Sri Lanka officially declared the University of Kelaniya in 1978, also launched their first academic periodical Kalyani in 1982. The main objective of this journal was to publish research related to humanities and social sciences.

The University of Ruhuna established during the same year launched Rohana, a multidisciplinary journal devoted to publishing research articles related to Applied \& Natural Sciences, Management \& Social Sciences, and Medical Sciences in 1985.

Three more titles were added to the list of journals published by universities during the latter half of the decade. Vingnanam Journal of Science was created by the University of Jaffna in 1986 to meet the need for publication of scientific research. Tropical Agricultural Research, the first journal to be published by a postgraduate institute in Sri Lanka was founded in 1988 by the Postgraduate Institute of Agriculture (PGIA) of the University of Peradeniya, (established in 1975). A journal dealing with a special aspect of agriculture, the Journal of the Agricultural Engineering Society of Sri Lanka, University of Peradeniya appeared during the latter part of the decade. Sri Lanka Journal of International Law emerged from the University of Colombo in 1989 while the University of Sri Jayewardenepura (the former Vidyodaya University) added the 
Vidyodaya Journal of Science during the same year. The Sri Lanka Journal of Buddhist Studies, launched by the Buddhist and Pali University of Sri Lanka in 1987, is the only journal in religious studies published by the universities.

During the 1980s, learned societies launched an increasing number of specialized journals. The Sri Lankan Journal of Anaesthesiology was published in the early 1980s by the College of Anaesthesiologists of Sri Lanka. Others include journals characterized by a variety of subjects such as chemistry, population studies, ethnic studies, economics and library science.

The first physical sciences periodical publication by a professional institution, Chemistry in Sri Lanka, was first issued in 1983 by the Institute of Chemistry (founded in 1971). The Journal of the Geological Society of Sri Lanka was launched in 1988 with the aim of publishing articles pertaining to any aspect of the earth sciences in Sri Lanka.

A new area of social science research emerged with the publication of Ethnic Studies Report in 1984. This journal published by the International Centre for Ethnic Studies (established in 1982) covers topics of ethnicity, ethnic conflict, and related issues reflecting the socio- political challenges of the period. Another new development during this time was the emergence of a new subject discipline, Library Science. Sri Lanka Library Review published by the Sri Lanka Library Association (formerly Ceylon Library Association established in 1960), emerged during 1986 providing a channel for Sri Lankan librarians to communicate professional concerns.

Gajah an academic journal dedicated to the conservation of a single animal species appeared in 1986. The journal first published as Asian Elephants Specialist Group Newsletter later took on the new name of Gajah and is intended as a medium of communication on issues that concern the management and conservation of Asian elephants both in the wild and in captivity. Two periodical publications covering the field of economic development emerged in 1986, namely the Sri Lanka Economic Journal, published by the Sri Lanka Economic Association and Upanathi by the Sri Lanka Association of Economists. The two Economic Associations and their respective publications were merged, resulting in the publication of the New Series of Sri Lanka Economic Journal in 2000.

\section{The 1990s}

While academic publishing in Sri Lanka during the previous decade was dominated by university publications, publications by professional institutions and learned societies dominated the nineties. Scholarly communications during the decade reflect the changing academic environment in the country and emergence of new subject areas and specializations. The expansion of the medical profession is reflected in the increase in medical publication since a majority of the of the journals were from the medical sciences. Some have special foci such as the Journal of Ruhunu Clinical Society, Sri Lanka Prescriber, Journal of the Collage of Ophthalmologists, Journal of the College of Community Physicians of Sri Lanka, and Sri Lanka Journal of Dermatology while 
others such as Kandy Medical Journal (1992) (continued by Sri Lanka Journal of Medicine) and Galle Medical Journal (1995) were general in nature. Sri Lanka Journal of Population Studies dealing with demography, a subject area close to the health sciences, was launched in 1998 by the Population Association of Sri Lanka.

Publications dealing with natural history increased during the $1990 \mathrm{~s}$, reflecting the growing interest in environment, biodiversity and endangered species. Herpetology one of the relatively new subject specialties in local natural history is the focus of the journal Lyriocephalus (Journal of the Amphibia and Reptile Research Organization of Sri Lanka) first published in 1993.

Another publication that specializes in the natural history of the region the Journal of South Asian Natural History was commenced in 1993, by the Wildlife Heritage Trust of Sri Lanka. This journal continues as Zeylanica. The Sri Lanka Naturalist, a journal specializing in Sri Lankan natural history, was launched by the Young Zoologists' Association of Sri Lanka towards the latter part of the decade. A new publication, Sri Lanka Journal of Aquatic Sciences, was launched in 1996 by the Sri Lanka Association for Fisheries and Aquatic Resources (established in 1994). This journal publishes articles in the field of aquatic sciences, including limnology, aquatic biology, and fisheries.

Academic trends reflected by the increasing diversity and specialization in local journals are seen to be closely related to sociological and political changes in the country. The Sri Lankan Journal of Agricultural Economics was launched in 1993 by the Sri Lanka Agricultural Economics Association and highlights the growing interest in agricultural economics, covering a broad range of topics from agricultural labour to environmental aspects related to local agricultural practice. Nivedini - Journal of Gender Studies commenced in 1993 by the Women's Education Centre (established in 1982) focuses on gender issues and related socioeconomic and political aspects and discussions. Nethra, a publication that seeks to create a forum for social, economic and political commentary, cultural, literary and artistic expression and exchange, was first published by International Centre for Ethnic Studies in 1996. The journal was reinvented as Nethra Review in 2010. The expansion in the field of librarianship is reflected in the founding of the Journal of the University Librarians Association in 1995.

The Sri Lanka Journal of Applied Statistics published by the Applied Statistics Association of Sri Lanka (founded in 1999) was a product of the expansion in study and research in the fields of physical and applied sciences.

Two scholarly periodicals specializing in education were launched during the 1990s by the National Institute of Education (NIE), Sri Lanka (established in 1986). Sri Lankan Journal of Educational Research, the first journal published by a government institution to focus on educational research, emerged in 1990. This was followed by the SAARC Journal of Educational Research covering educational developments and research in the South Asian region in the late 1990s. 
The 1990s saw an increased number of academic journals emerging from the newly established universities when compared with the older more established institutions of higher education. The Eastern University (established in 1981 as a University College and elevated to University status in 1986) published their first academic periodical, Agrieast, while Sabaragamuwa University (an affiliated University commissioned in 1992 and elevated to University status in 1995) came up with their first publication Sabaragamuwa University Journal in 1998. While Agrieast covered the subject area of agriculture, Sabaragamuwa University Journal included articles from all academic disciplines. The first issue of the journal, Tropical Agricultural Research and Extension (TARE) was launched by the University of Ruhuna in 1998 followed by a government publication the Annals of the Sri Lanka Department of Agriculture in 1999, providing additional venues for publishing articles on agriculture.

A further expansion of the subject areas covered by local publications occurred when the Postgraduate Institute of Management (PIM), a semi-autonomous body, affiliated with the University of Sri Jayewardenepura launched the Sri Lankan Journal of Management during the mid 1990s. Although the Open University of Sri Lanka (OUSL) was established in 1980, it was not until 1997 that the university began publishing the OUSL Journal, a publication specializing in distance education. Journal of the Faculty of Humanities \& Social Sciences, University of Ruhuna, commenced in 1998 providing an additional venue for research output in the area of humanities and social sciences.

\section{The 21 st Century}

Sri Lankan academic publishing in the new millennium is characterized by changes in the format of scholarly publications with the adoption of new information technology. The online format together with open access publishing has paved the way for increased accessibility of content. The International Network for the Availability of Scientific publications (INASP) played a major role in assisting the transition from print to digital publications leading to the development of Sri Lanka Journals Online (SLJOL - a database of online journals http://www.sljol.info/index.php/index) in association with the University of Colombo. By the end of 2010, 36 publications were available online via SLJOL while 3 were available via publishers' websites.

Tables of contents from 7 more publications were made available on the publishers' websites out of which two provide abstracts to articles. While SLJOL concentrates on providing access to scientific publications, the lack of abstracting and indexing publications and databases covering local humanities and social sciences subject areas has been partly compensated by the development of the Sri Lanka Research website (http://www.srilankaresearch.org/) by the author in 2010.

The last decade also saw an emergence of highly specialized subject areas reflecting new trends in the teaching and research. Developments in medical education since the 1950s with the addition of medical faculties in several universities, and the establishment of the Post Graduate Institute of Medicine led to the increase in the number of professionals working in highly specialized areas, resulting in the need for 
related professional societies and journals. This trend towards expressing their own unique voice is reflected in the journals founded during the last decade with publications such as Journal of Diagnostic Pathology by the College of Pathologists of Sri Lanka, Sri Lanka Journal of Urology (2000) by the Sri Lanka Association of Urological Surgeons (established in 1999), Bulletin Sri Lanka College of Microbiologists (2003), Sri Lanka Journal of Haematology (2002), Journal of Uva Clinical Society, Sri Lanka Journal of Venerology (2007), Kurunegala Med Journal (2009), and Sri Lanka Journal of Psychiatry (2010) by Sri Lanka College of Psychiatrists.

Among the university publications, the Sri Lanka journal of Critical Care was created by the Postgraduate Institute of Medicine, University of Colombo in 2009, to promote research, education and training in critical care medicine in Sri Lanka.

Sri Lanka Journal of Bio-Medical Informatics was launched by the Health Informatics Society of Sri Lanka (HISSL) and the Post Graduate Institute of Medicine (PGIM) to meet the needs of the rapidly evolving health sector move towards e-Health initiatives. Sri Lanka Journal of Forensic Medicine, Science \& Law was established in 2010 by the University of Peradeniya, filling a gap in local medical publications in that area.

Although the country has long history of indigenous medicine, institutionalization of the education in the local tradition was slow. However, over the past decades two University institutes of Ayurveda education were established in Sri Lanka and the Journal of Gampaha Wickramarachchi Ayurveda Institute was launched in 2004 by the Gampaha Wickramarachchi Ayurveda Institute; uplifted to the status of a university institute and affiliated to the University of Kelaniya in 1995.

Apart from the high number of medical publications, the period $2000-2010$ saw an increasing number of discipline specific publications by the universities. These include Vistas- Journal of Humanities and Social Sciences (2002) by the Open University of Sri Lanka, Journal of Science of the University of Kelaniya(2003), Journal of Agricultural Sciences, Sabaragamuwa University (2005), Sri Lankan Journal of Library \& Information Management (2005) by the National Institute of Library \& Information Science, (NILIS) University of Colombo, Ruhuna Journal of Science (2006), Journal of Food and Agriculture (2008) by the Wayamba University (established in 1999).

Inauguration of journals such as Sri Lankan Journal of Real Estate (2006) by the University of Sri Jayawardenapura, International Journal on Advances in ICT for Emerging Regions (2008) by University of Colombo School of Computing, Bhumi : the Planning Research Journal of University of Moratuwa (2009), and FARU Journal: Research Journal of the Faculty of Architecture University of Moratuwa (2009) reflect the changing academic environment and the expansion of the university curriculum towards new technology and applied research.

The Institute of Policy Studies was instrumental in launching the South Asia Economic Journal in 2000, jointly with the Research and Information System for Non-aligned and Other Developing Countries (RIS) of India, demonstrating a trend towards international 
collaborations in publications. Additions to the field of physical sciences include Sri Lanka Journal of Physics (2000) by the Institute of Physics and Built-Environment Sri Lanka (2000) by the Sri Lanka Institute of Architects.

Government publications during the period were limited to Governance Journal (2001) by the Sri Lanka Institute of Local Governance. Taprobanica: The Journal of Asian Biodiversity was launched in 2010 by the Taprobanica Nature Conservation Society reflecting the increased interest on biodiversity in the region. The main objective of the journal was to provide the opportunity to scientists working on the natural history of South Asia and Southeast Asia to publish their research.

\section{Discussion}

Figure 1 provides an overview of the growth of journal publications in Sri Lanka over the last 165 years. It shows a gradual growth during the first century followed by a rapid increase in publications during the last 50 years.

Figure 1 Number of Scholarly Journals Published in Sri Lanka by Subject, 1845 -2010

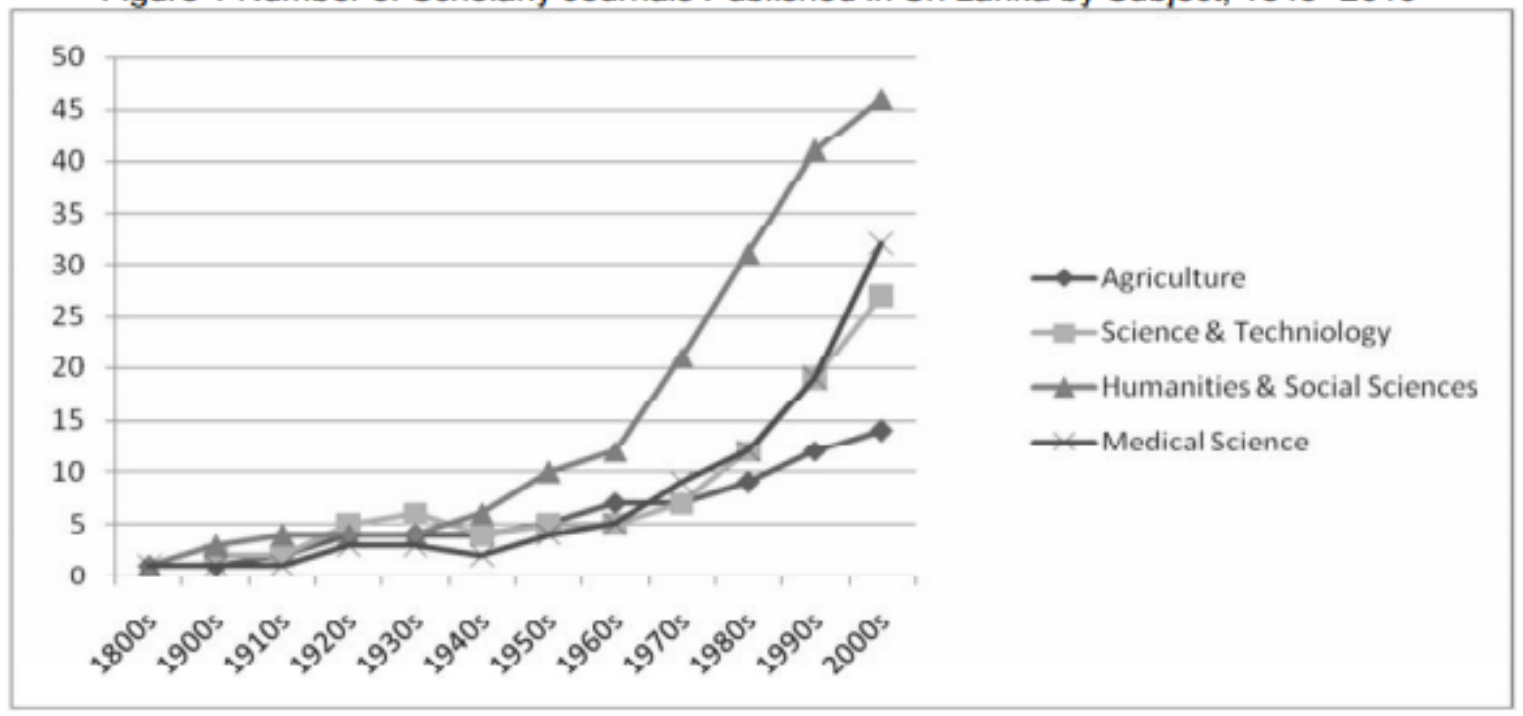

An increasing number of publications in a variety of subject areas were established during this period. However, some have ceased publication after a few years; others have remained and evolved through the years. Total number of journals increased from 45 in 1970 to114 in 2010. The highest number of titles was from the humanities and social sciences, followed by the medical sciences. Medical sciences showed the highest rate of growth during the last decade while science and agriculture periodicals increased gradually over the years. Overall, very few journals were published in the physical sciences although there was some growth in engineering and architectural studies during the period from 2000 to 2010 . 
Figure 2 Subject Distributions of Sri Lankan Journals

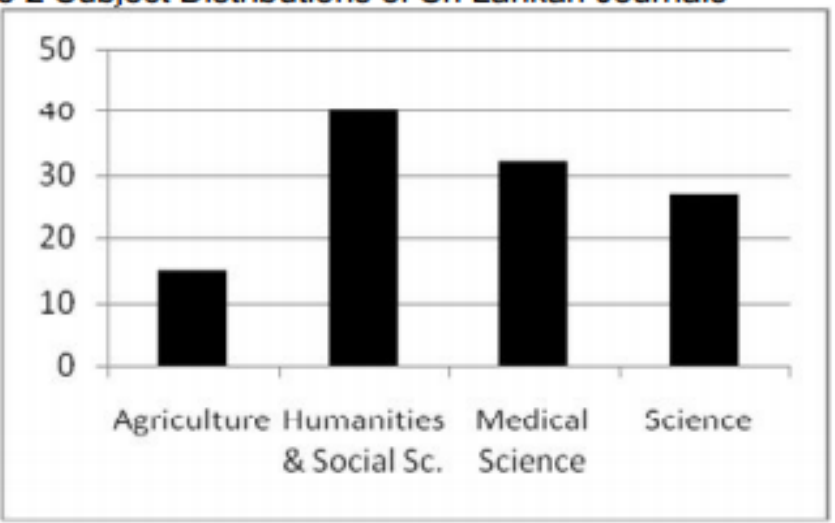

Overall subject distributions of Sri Lankan journals are displayed in Figure 2. According to available data, $35 \%$ of local periodicals are in the Humanities and social sciences, closely followed by $28 \%$ medical journals and $24 \%$ journals in the natural and physical sciences. The importance of agricultural journals is evident by the fact that $14 \%$ of local journals belong to this single subject category.

Professional organizations and learned societies were the major contributors to scholarly publishing in Sri Lanka. Figure 3 offers an overview of the distribution of publishers in the different subject areas. While professional organizations and learned societies play a major role in publishing medical journals, universities are the dominant publishers of journals in the humanities and social sciences. Most of the journals in the natural sciences are published by professional organizations and learned societies while publishing of agricultural journals is shared by universities and research institutes. Publications by governments departments were mainly from the agricultural sector. It is interesting to note that unlike in other parts of the world, scholarly publishing by local commercial publishers is virtually non-existent.

Figure 3 Distributions of Journals by Publisher

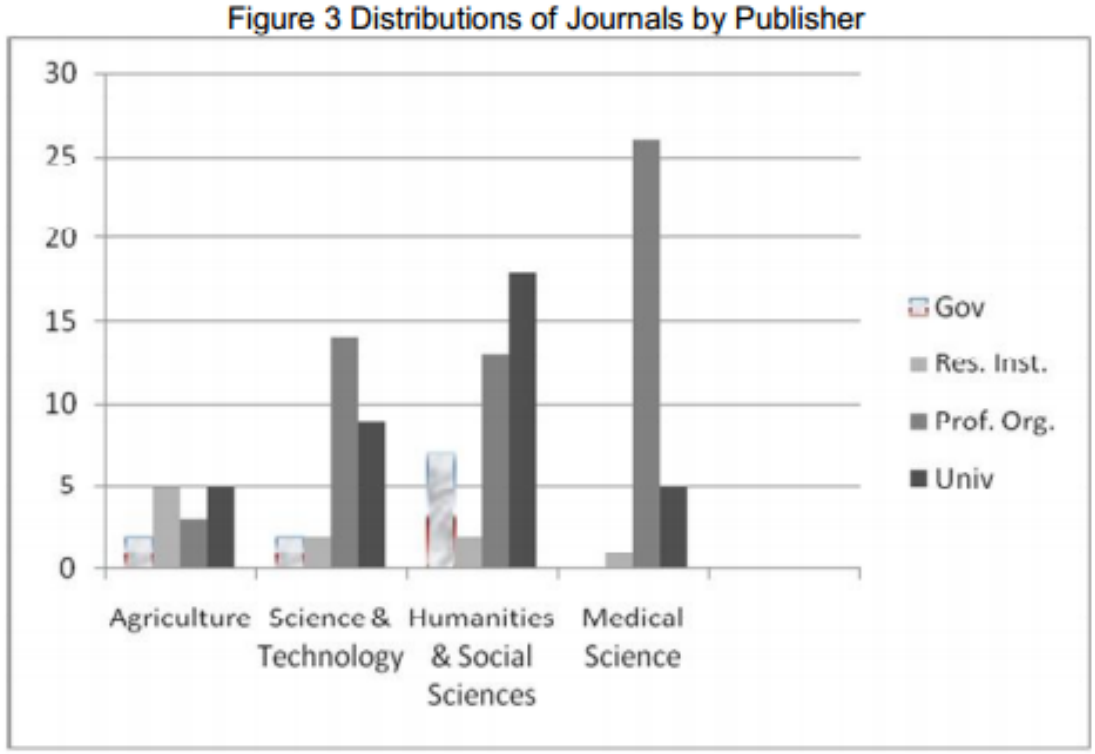




\section{Conclusion}

The historical development of scholarly publishing in Sri Lanka is closely linked to the developmental milestones of the country during the last 165 years. Local journal publishing began with publications that catered to the needs of the colonial elite, and has undergone considerable change over time since the country regained its independence. Several journals still remain from the colonial past and continue serving as valuable outlets for research publications in many subject areas.

Three publications launched during the 19 th century, namely the Journal of the Royal Asiatic Society of Sri Lanka (first called Journal of the Ceylon Branch of the Royal Asiatic Society of Great Britain \& Ireland), Tropical Agriculturist and Ceylon Medical Journal continue to play a major role in scholarly communications in Sri Lanka. The Ceylon Journal of Science established during this period continued to evolve with the changing academic environment while journals from the plantation sector continue to play a vital role in supporting the agricultural economy of the country.

The first university affiliated publications appeared in the early 1940 s, followed by rapid expansion in scholarly activities as reflected in the increasing number of publications following independence. Purely academic subject orientation of the post independence period publications gradually moved towards greater diversity of disciplines as the social and academic interests turned towards wider socio economic and political issues during the 1980s and 1990s. New academic publications founded during the 21 st century reveal a move towards greater specialization reflecting similar research trends in other parts of the world. The most important change in local academic publications during the last decade has been the change in the format of scholarly communications.

The introduction of online open access publications has made Sri Lankan scholarly journals available free of charge to any user, thereby expanding the horizons and enabling greater accessibility and visibility to local research.

\section{References}

Archer, M. (1959) 'India and Natural History - The Role of the East India Company,1785-1858.HistoryToday,vol.9,no.11, pp. 736-743.

Bronson, B. (1975) 'Ancient Ceylon: Journal of the Archeological Survey of Ceylon', American Anthropologist, vol. 77, pp. 151-152.

Crusz, H. (1973) 'Nature conservation in Sri Lanka (Ceylon)', Biological Conservation , vol. 5, no. 3, pp. 199-208.

Geiger, W. (1898) 'Archaeological Survey of Ceylon and its work', The Journal of the Royal Asiatic Society of Great Britain and Ireland , pp. 11-16. 
Gooneratne, Y. (1966) 'The Two Societies: A Study of Town Life in NineteenthCentury Ceylon', Historical Journal, vol.9, no. 3, pp 338-359.

Hodge, J. M. (2002) 'Science, development and empire: The coloial advisory council on agriculture and animal health,1929-43', The Journal of Imperial and Commonwealth History, vol. 30, no.1, pp. 1-26.

Journal of the Ceylon Branch of the Royal Asiatic Society,1845.Vol.1 Issue 1 Rules.

Porter, J. (1964) 'The Scientific Journal - 300th Anniversary', Bacteriological Reviews , vol. 28 , no. 3, pp. 211-230.

Schokman, D. (1981)"Tropical Agriculturist" (1881-1981)', Tropical Agriculturist, vol. 137, pp. 1-2.

Senadhira, A. (1975) 'The development of scientific journalism in in Sri Lanka' in Libraries and People, Colombo Public Library, Colombo, 261-270.

Spolia Zeylanica,(1904) 'The Periodic Literature of Ceylon', (1849) Calcutta Review , vol. 11, pp. 1-30.

Willis, J. (1901)'The Royal Botanic Gardens of Ceylon, and Their History’, Annals of the Royal Botanic Gardens, Peradeniya, vol. 1, pp. 1-15 